\title{
Accrual-Based International Public Sector Accounting Standards: Implementation Challenges Facing the Metropolitan, Municipal and District Assemblies in the Ashanti Region of Ghana
}

\author{
Joseph Kwasi Agyemang (Corresponding author) \\ Department of Accounting and Finance, Faculty of IT Business \\ Ghana Technology University College, Ghana \\ E-mail: jagyemang@gtuc.edu.gh/africa197676@yahoo.com
}

\begin{abstract}
Joseph Yensu
Department of Finance, Institute of Entrepreneurship and Enterprise Development

Kumasi Technical University, Kumasi, Ghana

E-mail: joseph.yensu123@gmail.com
\end{abstract}

Received: March 20, 2018

Accepted: April 16, 2018

Published: May 3, 2018

doi:10.5296/ijafr.v8i2.12860

URL: https://doi.org/10.5296/ijafr.v8i2.12860

\begin{abstract}
In recent times, the significance of Accrual-based Public Sector Accounting Standards (AIPSAS) in financial reporting is gaining momentum and current debates are moving in the trend of full AIPSAS reporting. Municipal, Metropolitan and District Assemblies (MMDAs) are not let off in this instance. The move to new reporting standards results in numerous challenges for diverse interest groups such accounting practitioners. The main objective of the study was to establish the AIPSAS implementation challenges facing MMDAs in the Ashanti region of Ghana. This quantitative study was conducted to gravely study the factors that could influence the implementation of AIPSAS. Purposive sampling procedure was used to select the departments whilst convenience sampling procedure was also used to select the sample size. A sample of 480 accounting practitioners was selected from all the 30 MMDAs in the Ashanti region of Ghana. Self administered questionnaire was used to gather data from
\end{abstract}


the respondents. The Pearson correlation and multiple linear regression analysis were used to test the significance level of the AIPSAS implementation factors. The results of the hypotheses tested revealed that with the exception of cultural practices, the level of accounting education and training, different levels of costs and the existing laws have significant effects on the implementation of AIPSAS in the MMDAs in the Ashanti region of Ghana.

Keywords: Accrual-based international public sector accounting standards, Implementation Challenges, Existing laws, Level of accounting education and training, Cultural practices, Different levels of costs

\section{Introduction}

In recent times, the significance of Accrual-based Public Sector Accounting Standards (AIPSAS) in financial reporting is gaining momentum and current debates are moving in the trend of full AIPSAS reporting. Municipal, Metropolitan and District Assemblies (MMDAs) are not let off in this instance. The move to new reporting standards results in numerous challenges for diverse interest groups such as accounting practitioners. The main objective of the study was to establish the AIPSAS implementation challenges facing MMDAs in the Ashanti region of Ghana. This quantitative study was conducted to gravely study the factors that could influence the implementation of AIPSAS. Purposive and convenience sampling procedure was used to select the sample. A sample of 480 accounting practitioners was selected from all the 30 MMDAs in the Ashanti region of Ghana. Self administered questionnaire was used to gather data from the respondents. The Pearson correlation and multiple linear regression analysis were used to test the significance level of the AIPSAS implementation factors. The study established that there is high AIPSAS implementation cost, inadequate training and education for accounting practitioners and academic education not focusing on IPSAS. It was again discovered that there is lack of a methodological relationship between existing local laws and IPSAS, lack of a methodological relationship between the regulatory systems of Ghana and other regulatory structures.

Another challenge discovered was that government influences makes AIPSAS implementation difficult in Ghana. The results of the hypotheses tested revealed that the level of accounting education and training, different levels of costs, existing laws, and cultural practices have significant effects on the implementation of AIPSAS in the MMDAs in the Ashanti region of Ghana. However, cultural practices have statistically insignificant relationship with AIPSAS implementation. As a result of these challenges, the study recommends improving capacity building through training and education and establishment of strong financial reporting standards' enforcement body. The study again recommends inclusion of AIPSAS in the academic curricula, inclusion of IPSAS implementation fund in the District Assemblies Common Fund (DACF) and involvement of regulatory bodies in standards setting at the international level. The study calls for the immediate non partisan politics at the public sector in Ghana in order to speed up the implementation of new accounting standards.

In a recent development, Prof Kwame Boasiako Omane-Antwi stated in a stakeholder's forum and launch of IPSAS in Accra on 11 February 2016 that Public sector entities would prepare 
their financial reports in line with the Accrual-based IPSAS by $31^{\text {st }}$ December 2016 (Omane-Antwi, 2016). It was mentioned that Ghana adopted Cash-based IPSAS in 2007 and the implementation of Accrual-based IPSAS (AIPSAS) will take effect from 2016. Accrual-based IPSAS will be the basis for the preparation of public sector accounts of Ghana for the year ended December 2016 (Omane-Antwi, 2016). However, a step-by-step approach to the implementation of Accrual-based IPSAS will be encouraged due to the complexity of the issues involved (Omane-Antwi, 2016). It was added that the adoption of AIPSAS followed a recommendation made by the ICAG, the Controller and Accountant-General's Department (CAGD) and the Audit Service.

The IPSAS, which is seen as a high quality worldwide financial reporting standards for use by public sector entities, would serve as the basis to prepare and present financial statements of public funds (Omane-Antwi, 2016). The IPSASB of the IFA is the first body to issue IPSAS which is meant to serve the public interest by requiring the presentation and disclosure of financial transactions in a comprehensive and consistent manner and to enhance transparency and the accountability of public resources (Omane-Antwi, 2016). Omane-Antwi (2016) recognised the fact that public sector entities that will adopt and implement Accrual -based IPSAS would face some challenges.

Accrual accounting is a method of recording financial transactions where the full characteristics of those transactions are recorded in the period to which they relate. All assets owned by the organisation at the end of the period and all liabilities which exist at that point is also recognised in the financial statements. In particular it records revenues earned and resources consumed in a period rather than simply reflecting the cash movements

Public sector entities include national governments, regional governments, local governments and related governmental entities, unless otherwise stated.

Cash accounting has dominated in the area of government accounting as the traditional method in most of countries including Ghana (Omane-Antwi, 2016). It is applied widely in the field of government financial management as a means of controlling the movement of cash (Omane-Antwi, 2016). However, the situation has changed from the end of 20th century. The accrual basis of accounting becomes the main topic of new public management especially within the process of government accounting transformation (Chan, 2003). The increasing demand for accountability by the people of Ghana shall no doubt be served with a system that increases transparency and accountability and this aspiration of the people will be better served by the full implementation of Accrual-based IPSAS (Grace, 2015).

Previous studies on IPSAS adoption have indicated that any accounting transition is bound to be characterised with challenges (Alp and Ustundag, 2009). Ghana may face the practical implementation challenge since implementation requires professional accountants and regulators who may be in short supply in the public sector (Martins, 2011). This view was also pointed by United Nations (2006) in the adoption analysis. 


\section{Macrothink}

International Journal of Accounting and Financial Reporting

ISSN 2162-3082

2018, Vol. 8, No. 2

As Ghana's most important economic sector managing the state's funds, Accrual-based IPSAS in Ghana is not an exploited area to enhance investment opportunities. It is clearly believed that the accounting practitioners in the public sector in Ghana would face some challenges in the implementation and the application of Accrual-based IPSAS (Omane-Antwi, 2016). In contrast, Ghana Companies Code 1963 (Act 179) and the Ghana National Accounting Standard, which serve as a benchmark for the treatment of financial transactions and the preparation of financial statements provided for the modified basis of financial reporting but failed to give basis for the treatment of financial assets in the financial reports using accrual basis. Also, the presentation and treatment of financial resources was different from the GNAS as compared to the Accrual-based IPSAS. However, now that Ghana has made mandatory adoption of Accrual-based IPSAS for all Metropolitans, Municipals and District Assemblies (MMDAs) in the public sector, how would the implementation of Accrual-based IPSAS be? Therefore, the challenges of Accrual-based IPSAS adoption in Ghana should be established and addressed for the economy to benefit fully from the adoption and implementation. It is against this background that this study intends to investigate the Accrual-based IPSAS implementation challenges facing the MMDAs in the Ashanti Region of Ghana.

Deaconu, et al. (2011) researched into the impact of accrual accounting on public sector management: An exporatory study for Romania. Deaconu, et al. (2009) again studied the Effect of Transiting from Cash Accounting to Accrual Accounting on Performance in the Public Sector. Christiaens, et al. (2013) researched into the Effect of IPSAS on Reforming Governmental Financial Reporting. Acquaye (2015) conducted study on the Adoption of International Financial Reporting Standard (IFRS) by Ghanaian companies the level of compliance with reference to the preparation of financial statement. Agyemang (2016) also conducted a study on the Fair value implementation challenges facing SMEs in the agricultural sector in Ghana. These previous studies were based on qualitative analysis and no hypotheses were also tested. However, since Ghana adopted accrual basis of accounting in the public sector in 2016, no study has been conducted to look at the implementation challenges accounting practitioners are facing in Ghana. Therefore this study intends to fill this gap by looking at the AIPSAS implementation challenges facing the MMDAs in the Ashanti region of Ghana. It is the first of its kind in Ghana. No study has been conducted on Accrual-based IPSAS implementation challenges facing MMDAs in Ghana. It is also the first time of using predictions (testing of hypothesis) in a study of such nature in Ghana and some other countries.

\subsection{Objective of the Study}

The main objective of the study was to ascertain the implementation challenges of Accrual-based IPSAS by MMDAs in the Ashanti Region of Ghana. Specifically, the study sought to:

i. Determine how the cultural practices affect the implementation of Accrual-based IPSAS in the MMDAs in the Ashanti Region of Ghana

ii. Examine the level of accounting education and training on the practical implementation of Accrual-based IPSAS in the MMDAs in the Ashanti Region of Ghana. 


\section{Mll Macrothink}

International Journal of Accounting and Financial Reporting

ISSN 2162-3082

2018, Vol. 8, No. 2

iii. Discover how the different levels of cost affect the implementation of Accrual-based IPSAS in the MMDAs in the Ashanti Region of Ghana

iv. Examine the effect of existing laws on the smooth implementation of Accrual-based IPSAS in the MMDAs in the Ashanti Region of Ghana.

\subsection{The Following Hypotheses Were Tested}

Ho1: There is a significant relationship between levels of cost and Accrual-based IPSAS implementation

Ho2: There is a significant relationship between level of accounting education and training and Accrual-based IPSAS implementation

Ho3: There is a significant relationship between the existing laws and Accrual-based IPSAS implementation

Ho4: There is a significant relationship between cultural practices and Accrual-based IPSAS implementation

\section{Accrual-Based IPSAS Implementation Challenges in the Public Sector}

The conceptual framework was constructed based on the objectives of the study. AIPSAS implementation challenges were explained in line with the conceptual framework. The conceptual framework explains the effect of existing laws, accounting education and training, cultural practices and the different levels of costs on the implementation of AIPSAS in the MMDAS in the Ashanti Region of Ghana. The challenges of AIPSAS implementation in Ghana should be identified and addressed for the economy to benefit fully from the implementation. Therefore, the factors affecting the implementation of AIPSAS are explained in the conceptual framework below:

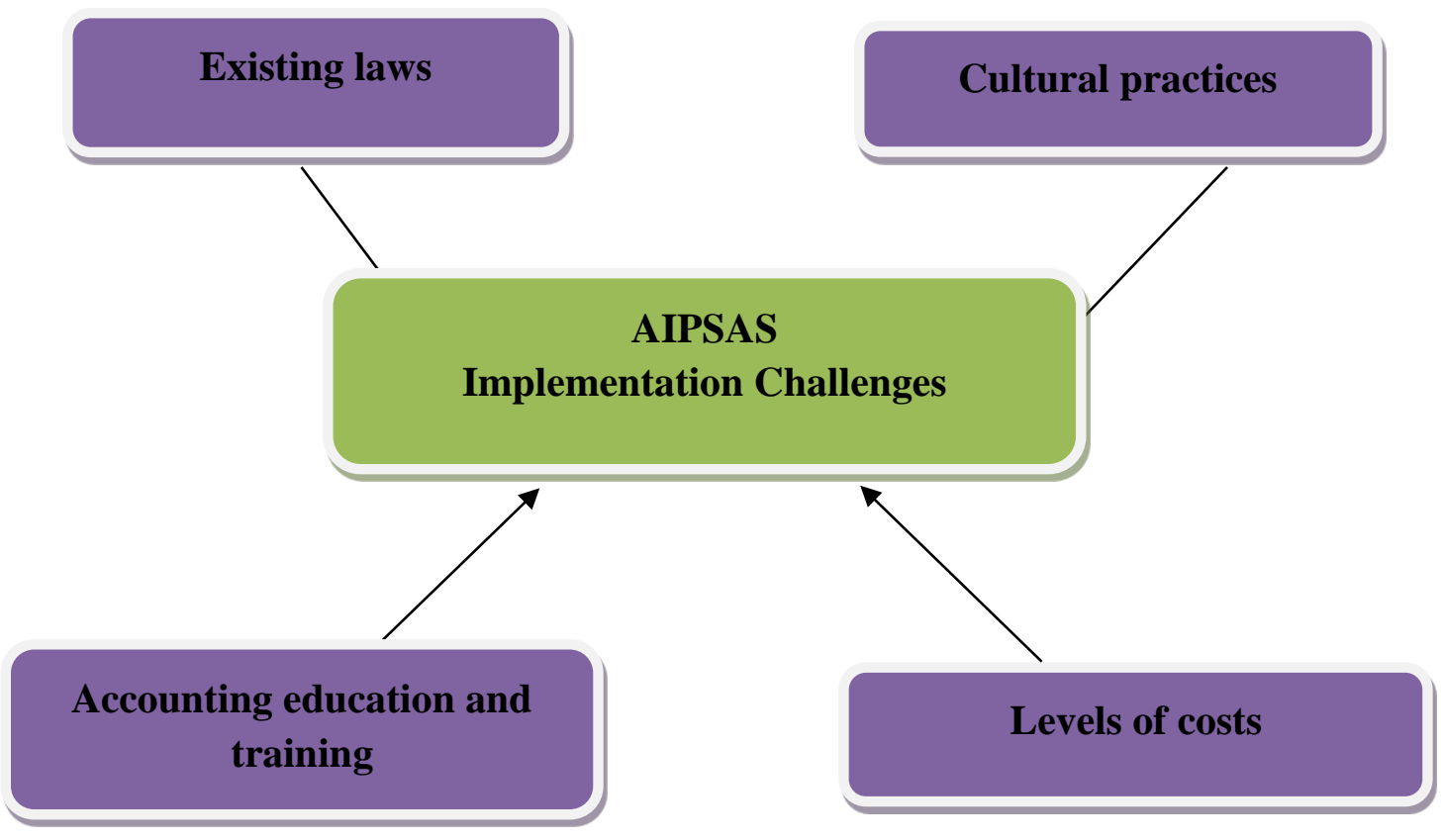

Figure 1. Conceptual framework 


\subsection{Existing Laws and AIPSAS Implementation Challenges}

Amendments to existing laws may be required in the implementation process of AIPSAS. The public sector accounting in Ghana is mainly governed by the Public Finance Management Act. Provisions of the Act and the AIPSAS may conflict materially requiring the regulators to converge the Act and the IPSAS for smooth transition (Li and Meeks, 2006). Li and Meeks (2006) mentioned that if accounting standards are integrated with the legal systems, the application becomes mandatory for all entities.

Kothari (2000) contended that the benefit of accounting standards with enforcement determines the value of accounting information. Zeff (1995) expressed that there ought to be an alliance between a standard setting body and that of government regulatory body. In Ghana, the accounting practices are governed by the Companies Code 1963 (Act 179), and the Ghana Accounting Standards issued by the ICAG and other existing laws, for example, Securities and Exchange Commission Regulations (2003), the Securities Industry Law (1993), and Banking Act (2004). All these give certain guidelines on the preparation of financial reports in Ghana. AIPSAS does not recognise the existence of these laws, and the accounting practitioners have to follow the AIPSAS fully with no prevailing provisions from these laws (ICAG, 2010). Regulatory bodies in Ghana may need to make vital amendments to guarantee a smooth move to AIPSAS. The hypothesis tested in the study of Mehrnaz (2017) equally demonstrated that there is a significant relationship between the independent variable of existing laws and the implementation of international accounting standards.

\subsection{Cultural Practices and AIPSAS Implementation Challenges}

Culture has been referred to as "the aggregate programming of the mind which recognises individuals from one group of people to another" (Hofstede, 1980, p. 25). The distinctions in culture, in the context of history or in the elements of structure of every country may impact the reforms in the public sector and the accounting frameworks (Benito et al., 2007; Pina et al., 2009). Ghanaian culture is both masculine and feminine however the prevailing role in Ghanaian society belongs to feminine. Hofstede (1991) mentioned that culture has an essential influence in the way of life of associations. This social factor is probably going to impact the political and economic structure of associations within Ghana and different countries and consequently should be considered when exploring current practices and policies in the context of Ghana for accounting practitioners. Pina, et al. (2009) hypothesised that there is a significant relationship between cultural practices and the implementation of international accounting standards.

\subsection{Different Levels of Costs and AIPSAS Implementation Challenges}

Edogbanya and Kamardin (2014) indicated that there is high cost of personnel training in the implementation of international accounting standards. The cost of training accounting and audit staff will result in high expenses, which may be more than the total benefits of international accounting standards implementation. Prewitt (2013) argued that the cost of training is a hindrance to most entities in developing countries when it comes to the implementation of international accounting standards. 


\section{MlMacrothink}

International Journal of Accounting and Financial Reporting

ISSN 2162-3082

2018, Vol. 8, No. 2

Jaarat and Tabari (2013) argued that international accounting standards are complex and difficult to understand by most accounting practitioners. The implementation of international accounting standards has implications for changes in academic curriculum in the various educational institutions. Okpala (2012) results revealed that there is a significant relationship between implementation of accounting standards and cost such as cost of converting the existing record, the cost involved in training and employment of suitable manpower, and the cost of discarding the existing accounting infrastructure.

\subsection{Level of Accounting Education and Training and AIPSAS Implementation Challenges}

Street (2002) stated that countries with low level of education and weak expertise fail in the implementation of international accounting standards. Professional accountants are looked upon to ensure successful implementation of AIPSAS. Along with these accountants, government officials, financial analysts, auditors, tax practitioners, regulators, accounting lecturers, stock-brokers, preparers of financial statements and information officers are all responsible for smooth adoption process. Training materials may not be readily available at affordable in Ghana to train all the accounting practitioners in the MMDAS which may create a big challenge to AIPSAS adoption. As a result, Ghana may face AIPSAS implementation challenges. According to Iyoha and Jimoh (2011) the education and training of accountants have strong implications for international accounting standards implementation. The authors additionally concluded that education and training are imperative for the successful implementation of international accounting standards.

\section{Research Method}

Self administered questionnaire was used to gather data from the respondents. The Pearson correlation and multiple linear regression analysis were used to test the significance level of the factors that affect the implementation of AIPSAS. The questionnaire consisted of 40 questions for the factors affecting the implementation of AIPSAS. However, 20 questions were also asked to ascertain the knowledge of the accounting practitioners on the AIPSAS. Therefore, a total of 60 questions were used to achieve the objective of the study.

The total population was 919 accounting practitioners in the 30 MMDAs. A sample size of 480 accounting practitioners in all the 30 MMDAs in the Ashanti Region was used in the study. The study adopted convenience sampling technique to select from each department the budget officers, Account Officers, Revenue Officers and auditors working in the MMDAs as the sample units. 


\section{Macrothink \\ International Journal of Accounting and Financial Reporting \\ ISSN 2162-3082 \\ 2018, Vol. 8, No. 2}

Table 1. Determination of sample size of accounting practitioners

\begin{tabular}{lcc}
\hline \multicolumn{1}{c}{ Departments } & Total number of employees & $\begin{array}{c}\text { Total number of employees } \\
\text { selected }\end{array}$ \\
\hline Budget & 78 & 50 \\
\hline Accounts & 175 & 150 \\
\hline Revenue & 590 & 230 \\
\hline Audit & 76 & 50 \\
\hline Grand Total & $\mathbf{9 1 9}$ & $\mathbf{4 8 0}$ \\
\hline
\end{tabular}

Table 1 illustrates the distribution of the sample size in respect of the various MMDAs in the Ashanti Region. As a result of the limited resources and lack of similar research in Ghana, a sample size of 480 accounting practitioners was used in this study.

\subsection{Sampling Technique}

Non-probability sampling based on purposive sampling was used in this study. Purposive sampling is restricted to specific types of people who can make available the desired information, for instance account officers, auditors, budget officers and revenue officers from the MMDAs.

\subsection{Variables}

In this study, the dependent variable is the AIPSAS implementation challenges. The four independent variables are Level of Accounting Education and Training, Different Levels of Costs, Existing Laws and Cultural Practices.

\subsection{Data Analysis}

The Statistical Package for the Social Sciences (SPSS) was used to organise and process the data for analysis.

Four hypotheses were formulated and tested using one-way ANOVA model at 5\% level of significance. SPSS was used as the ranking procedures in the questionnaire. The study used closed-ended or structured questions. The questionnaire was self administered. A multiple regression model was used as a fundamental test to measure the relationship between the variables and the strength of their association. A multiple regression model was derived using the questionnaire survey. In the model, AIPSAS implementation is a dependent variable whilst AIPSAS implementation factors (level of accounting education and training, different levels of costs, existing laws and cultural practices) are independent variables. 


\section{Discussion of Results}

Table 2. Descriptive statistics of the dependent variable, implementation of AIPSAS and four independent variables

\begin{tabular}{lccccc}
\hline & $\mathrm{N}$ & Minimum & Maximum & Mean & Std. Deviation \\
\hline LEVELOFACC & 480 & 25.20 & 45.50 & 40.2346 & 4.31373 \\
LEVELOFCOST & 480 & 23.40 & 45.50 & 40.2669 & 4.44895 \\
EXISTLAW & 480 & 23.40 & 45.50 & 40.6285 & 4.13408 \\
CULPRA & 480 & 23.40 & 45.50 & 40.7031 & 4.00133 \\
DP & 480 & 13.12 & 35.62 & 32.0266 & 3.95585 \\
Valid N (listwise) & 480 & & & & \\
\hline
\end{tabular}

As indicated on Table 2 above, the minimum value of the mean for the dependent variable of AIPSAS implementation is 13.12 with a standard deviation of 3.95585 and the maximum value of the mean is 35.62 with a standard deviation of 3.95585. This positive high mean value indicates that most respondents agree with the implementation of AIPSAS by MMDAs. Additionally, the standard deviation and the mean scores for the independent variables (level of accounting education and training, different levels of costs, existing laws, and cultural practices) with ten items on five point Likert scale shows a minimum of 40.2346 with a standard deviation of 4.313, and a maximum of 40.7031 with a standard deviation of 4.001 respectively. Since all the ten items mean score exceeds 40.0, it could be argued that majority of the respondents agreed with the questions.

\subsection{Pearson Correlation Analysis}

The analysis of Pearson correlation is a measure of the connection between two factors with values involving +1 and -1 . It is broadly applied in the sciences as a measure of the strength of linear dependence between two factors. In Pearson Correlation analysis, the P-value endeavours to give a measure of the measure of the strength of results of a test, in contrast to a simple reject or do not reject decision. In Pearson correlation analysis, the value of strength of relationship ( $r$ ) assumes an imperative part in deciding the level of associations among factors. The level of significance, $\mathrm{p}<0.05$ is additionally used to build up the relationship. This level of significance demonstrates that there is just 5 percent chance that the relationship does not exist, and 95 times out of 100 times the relationship among factors could be said to have a significant relationship. The table beneath demonstrates the Pearson correlation analysis results among the variables, testing of the hypothesis and the explanation of the results of the Pearson correlation is presented in a separate section with the results of the regression analysis. 


\section{1l Macrothink \\ International Journal of Accounting and Financial Reporting \\ ISSN 2162-3082 \\ 2018, Vol. 8, No. 2}

Table 3. Correlations

\begin{tabular}{|c|c|c|c|c|c|c|}
\hline & & DP & $\begin{array}{l}\text { LEVELOF } \\
\text { ACC }\end{array}$ & $\begin{array}{l}\text { LEVELOFC } \\
\text { OST }\end{array}$ & $\begin{array}{l}\text { EXISTLA } \\
\mathrm{W}\end{array}$ & $\begin{array}{l}\text { CULPR } \\
\text { A }\end{array}$ \\
\hline \multirow{5}{*}{$\begin{array}{l}\text { Pearson } \\
\text { Correlation }\end{array}$} & DP & 1.000 & & & & \\
\hline & $\begin{array}{l}\text { LEVELOFA } \\
\text { CC }\end{array}$ & .797 & 1.000 & & & \\
\hline & $\begin{array}{l}\text { LEVELOFC } \\
\text { OST }\end{array}$ & .863 & .802 & 1.000 & & \\
\hline & EXISTLAW & .808 & .781 & .801 & 1.000 & \\
\hline & CULPRA & .822 & .847 & .841 & .869 & 1.000 \\
\hline
\end{tabular}

As shown in the above Table 3, of the total of four explanatory variables tested in this study, there is a significant correlation between four of the independent variables (level of accounting education and training, different levels of costs, existing laws, and cultural practices) and the dependent variable i.e. implementation of AIPSAS by MMDAs in Ghana. Based on the results in Table 3, there are positive relationships between AIPSAS implementation and all the independent variables, these shows that most of the hypotheses are supported. The correlation coefficient of the level of accounting education and training is 0.797 . This implies that as the level of accounting education and training increases, the AIPSAS implementation challenges also increases.

\subsection{Multiple Regression Analysis}

In this section, in examining the factors that could affect the implementation of AIPSAS by MMDAs in Ghana, the study adopted a regression analysis to test the effect of four independent (explanatory) variables on the dependent variable (the implementation of AIPSAS). Thus, the study adopted multiple regression analysis to test one or more independent variables' influence the variation on dependent variable. The functional relationship between variables in this study is therefore, the implementation of AIPSAS is a function of level education and training, different levels of costs, existing laws, and cultural practices. However, to show how well the model containing those of four explanatory variables actually explains the variations in the dependent variable (implementation of AIPSAS), it is necessary to test it through goodness of fit statistic. 


\section{Macrothink \\ International Journal of Accounting and Financial Reporting \\ ISSN 2162-3082 2018, Vol. 8, No. 2}

Table 4. Goodness of fit through R Square

Model Summary

Change Statistics

Adjusted Std. Error of

Sig. F

R Square R Square the Estimate R Square Change FChange df1 df2 Change

.796

.794

1.79573

.796

$462.379 \quad 4 \quad 475$

.000

a. Predictors: (Constant), CULPRA, LEVELOFCOST, LEVELOFACC, EXISTLAW

On Table 4 above, both $\mathrm{R}^{2}$ and adjusted $\mathrm{R}^{2}$ measure the fitness of the model i.e. they measure the proportion of the variation in dependent variable explained by the model. But since adjusted $\mathrm{R}^{2}$ is the modification for the limitation of $\mathrm{R}^{2}$ the value of the adjusted $\mathrm{R}^{2}$ is considered to measure the fitness of the model. Thus, as it is shown on Table 4, the value of adjusted $\mathrm{R}^{2}$ is 0.794 , indicating that the independent variables in the model are explaining $79.4 \%$ variation on the dependent variables. Thus, we can understand that the model of the study is providing a good fit to the data. This outcome empirically indicates that the independent variables in this study are the major determinants of AIPSAS implementation challenges.

Table 5 below shows the results of the regression model. The result reveals that there exists a significant relationship between independent variables such as level of accounting education and training, different levels of costs, existing laws, and cultural practices and dependent variable, i.e. implementation of AIPSAS.

Table 5. Testing the model through ANOVA (Goodness of fit statistic)

\begin{tabular}{|c|c|c|c|c|c|c|}
\hline Model & & $\begin{array}{l}\text { Sum } \\
\text { Squares }\end{array}$ & Df & Mean Square & $\mathrm{F}$ & Sig. \\
\hline \multirow[t]{3}{*}{1} & Regression & 5964.045 & 4 & 1491.011 & 462.379 & .000 \\
\hline & Residual & 1531.710 & 475 & 3.225 & & \\
\hline & Total & 7495.755 & 479 & & & \\
\hline
\end{tabular}

a. Predictors: (Constant), CULPRA, LEVELOFCOST, LEVELOFACC, EXISTLAW

b. Dependent Variable: DP 


\section{Mll Macrothink}

International Journal of Accounting and Financial Reporting

ISSN 2162-3082 2018, Vol. 8, No. 2

The Table 5 above gives a summary of information relating to the explanation of how the independent variable varies with the existing model used in this research. The table again indicates that the variation of the dependent variable that are not captured by the model. It is seen that the independent variable gives a significant effect on the dependent variable. It could be observed from the table that F-value is 462.379 with a p-value less than 0.05 (i.e. $\mathrm{p}<0.000$ ). This demonstrates that, over all, the model used in the study is fundamentally adequate in clarifying the variation on the dependent variable. To guarantee the statistical adequacy of the model, the goodness is measured by the square of the correlation coefficient $\left(\mathrm{R}^{2 .)}\right.$

Table 6. Regression analysis on AIPSAS implementation

\begin{tabular}{|c|c|c|c|c|c|c|}
\hline \multirow{2}{*}{\multicolumn{2}{|c|}{ Model }} & \multicolumn{3}{|c|}{$\begin{array}{r}\text { Standardized } \\
\text { Unstandardised Coefficients Coefficients }\end{array}$} & \multirow{2}{*}{\multicolumn{2}{|c|}{$\begin{array}{l}\mathrm{Si} \\
\text { g. }\end{array}$}} \\
\hline & & $\mathrm{B}$ & Std. Error & Beta & & \\
\hline \multirow[t]{5}{*}{1} & (Constant) & -3.311 & .859 & & -3.856 & .000 \\
\hline & LEVELOFACC & .156 & .038 & .170 & 4.127 & .000 \\
\hline & LEVELOFCOST & .430 & .037 & .483 & 11.672 & .000 \\
\hline & EXISTLAW & .200 & .042 & .209 & 4.786 & .000 \\
\hline & CULPRA & .089 & .052 & .090 & 1.718 & .086 \\
\hline
\end{tabular}

a. Dependent Variable: DP

As shown in the Table 6 above, three out of the total four explanatory variables tested in this study, level of accounting education and training ( $p$-value $=0.000)$, level of costs (p-value $=0.000$ ), existing laws ( $p$-value $=0.000$ ), were statistically significant at 5 percent or lower. The Table shows that cultural practices ( $p$-value $=0.086$ ) is statistically insignificant.

The study shows a significant positive relationship between level of accounting education and training and implementation of AIPSAS with a regression coefficient of 0.170 , and P-value of 0.000 . This explains that $17 \%$ of accounting education's contribution to the implementation of AIPSAS is significant or high. That is it explains $17 \%$ of the variance in the implementation of AIPSAS. The result of this study is consistent with the conclusions made by Iyoha and Jimoh (2011), Sharif (2010), and Wong, (2004). According to Iyoha and Jimoh (2011) the education and training of accountants have strong implications for international accounting standards implementation

There is also a significant positive relationship between different levels of costs and implementation of AIPSAS with a regression coefficient of 0.483 , and P-value of 0.000 . This 
explains that $48.3 \%$ of level of costs' contribution to the implementation of AIPSAS is significant or high. That is it explains $48.3 \%$ of the variance in the implementation of AIPSAS. Consistent with the result of this study is Okpala (2012). Okpala (2012) results revealed that there is a significant relationship between implementation of accounting standards and cost.

There is again a significant positive relationship between existing laws and implementation of AIPSAS with a regression coefficient of 0.209 , and P-value of 0.000 . This explains that $20.9 \%$ of existing laws' contribution to the implementation of AIPSAS is significant or high. That is it explains $20.9 \%$ of the variance in the implementation of AIPSAS. The finding of this study is supported by Mehrnaz (2017). Mehrnaz (2017) hypothesised that there is a significant relationship between existing laws and the implementation of international accounting standards.

However, the study shows an insignificant positive relationship between cultural practices and implementation of AIPSAS with a regression coefficient of 0.090, and P-value of 0.086. The result also reveals that there is no positive relationship between all the independent variables and the implementation of AIPSAS. This explains that $0.9 \%$ of cultural practices' contribution to the implementation of AIPSAS is marginal or very low. That is it explains $0.9 \%$ of the variance in the implementation of AIPSAS. Pina, et al. (2009) hypothesised that there is a significant relationship between cultural practices and the implementation of international accounting standards. The findings from this study contradict that of Pina, et al. (2009).

\section{Conclusion}

The study aimed to establish the AIPSAS implementation challenges confronting the MMDAs in the Ashanti region of Ghana. A detailed literature was reviewed on AIPSAS implementation challenges in and outside Ghana. The Pearson correlation and multiple linear regression analysis were used to test the significance level of the AIPSAS implementation factors. The results of the study revealed that variables including level of accounting education and training, different levels of costs, existing laws, and with the exception of cultural practices, have significant effect on the implementation of AIPSAS in MMDAs in the public sector of Ghana. The study indicated that the academic curricula do not contain detailed public sector accounting in Ghana. This has called for the AIPSAS implementation challenges in the public sector of Ghana.

It was revealed that the implementation of AIPSAS is complex, and therefore, its enforcement at the MMDAs in the Ashanti region of Ghana is difficult. Accordingly, accounting regulatory bodies may give synopsis information on the application of AIPSAS in public sector of Ghana. It was additionally demonstrated obviously that AIPSAS implementation has brought about an essentially better quality of financial reporting in Ghana. This surmises high quality financial reporting will raise the confidence level of government and other interest groups in financial reports as the financial reports will demonstrate a true and fair view of the state of affairs of the public sector entity. It was similarly settled from the respondents that masculinity, individualism, organisational structure and resistance to change will influence the implementation of AIPSAS. 


\section{Mll Macrothink}

International Journal of Accounting and Financial Reporting

ISSN 2162-3082

2018, Vol. 8, No. 2

It was clearly indicated by the respondents that academic education does not give attention to AIPSAS. This affirms clearly that there is absence of synchronization between traditional training and professional programmes. It was again demonstrated by the respondents that the training and education of the accounting practitioners for smooth implementation of AIPSAS in the MMDAs in the Ashanti region of Ghana is lacking. Thus, management of MMDAs has to organise training programmes for accounting practitioners in order to ensure an efficient implementation of AIPSAS.

Another challenge discovered was that government influences makes AIPSAS implementation difficult in Ghana. This is an indication that the ruling government normally influences public sector employees which makes accounting transition very complex. It therefore calls for the immediate non partisan politics at the public sector in Ghana in order to speed up the implementation of new accounting standards.

The study again revealed that cost of implementing and enforcing AIPSAS in the MMDAs in the public sector of Ghana are extremely high. As per Smith (2009), transition costs are different from one entity to another, and others are similar to all entities across the globe. This implies that accounting regulatory bodies must take the pain in the process of implementing and enforcing AIPSAS. This additionally infers government and the management of MMDAs in the public sector to enlist and select qualified persons amid the employment process in order to avoid cost of training after selection.

Absence of a methodological relationship between existing Ghanaian laws and IPSAS was likewise uncovered as one of the AIPSAS implementation difficulties of MMDAs in Ghana. A comparative affirmation was made that there is contradiction between existing IPSAS and laws at the country levels. This infers the rules governing the preparation and reporting of accounts is totally different from IPSAS. It was additionally uncovered that there is absence of a methodological correlation between the accounting regulatory system of Ghana and other regulatory structures. This implies the body in responsible for setting accounting standards in Ghana is not included at the global level where IPSAS is set.

However, the study depicted how these challenges influence the financial reporting quality. The study recommended potential enhancements in order to have comparable and reliable financial reporting in the public sector of Ghana. The commendation corresponds to the global financial reporting standards, appropriate methods to simplify and harmonise reporting. This may help to triumph over such difficulties effectively and efficiently. Additionally, this research has created a platform to orient accounting practitioners in the MMDAs in the public sector of Ghana.

The information available to the researcher indicates that this is the first broad research on Accrual-based IPSAS implementation challenges in Ghana. It is the first of its kind in Ghana. No study has been conducted on Accrual-based IPSAS implementation challenges facing MMDAs in Ghana. It is also the first time of using predictions (testing of hypothesis) in a study of such nature in Ghana and some other countries. 


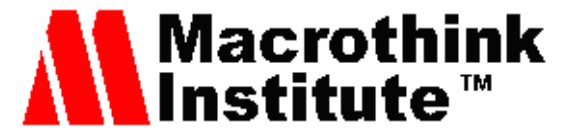

International Journal of Accounting and Financial Reporting

ISSN 2162-3082

2018, Vol. 8, No. 2

Again, the final outcomes of this study provided evidence of accounting practitioners' knowledge in Accrual-based IPSAS in order to devise means for effective implementation of an international financial reporting standard as a way of improving the value of financial reporting in the MMDAs in Ghana.

It also added to the existing literature and helped create the essential feeling for further studies in Ghana and other parts of the world. This study could also be a useful source of information to develop curriculum on international financial reporting standards in tertiary institutions in Ghana. The recommendations from this study could be adopted to improve accounting practitioners' capabilities of which at the end will affect the public sector at large.

Results from this study could be much interest to policymakers concerned with IFRS adoption and implementation in Ghana. Targeting IFRS education programmes to the groups that need them most could increase their effectiveness. Information on the level of accounting education and training and the knowledge of accounting practitioners on Accrual-based IPSAS from this study could aid policymakers to develop training programmes on the adoption of new international accounting standards.

This research added to the Ghana Audit Service (GAS), International Accounting Standards Board (IASB), Institute of Charted Accountants Ghana (ICAG) and the World Bank agenda in promoting international accounting standards implementation in developing and emerging economies because of the advantages international accounting standards have on financial reporting.

This research could be imperative to the Ghanaian economy as the Accrual-based IPSAS would result in transparency in the activities in the public sector of Ghana. Emerging countries would also benefit fully from this study when they decide to implement AIPSAS notwithstanding the technology, expertise and other challenges existing. The research also discovered information gaps and proposed areas for additional research.

In practice, the findings of this study helped to come up with implementation guidance of Accrual-based IPSAS. A guide to implement an international accounting standard is paramount when such a standard is adopted for the first time.

\section{Recommendations}

This study suggests that the accounting regulatory bodies in Ghana ought to arrange standard training and seminars for entities that have implemented or those in the process of implementing it with more accentuation on AIPSAS for MMDAs in the public sector of Ghana. This quantitative study clearly demonstrates that there is insufficient education and training for the smooth implementation of AIPSAS in Ghana. Organising seminars regularly for the accounting practitioners in MMDAs in the public sector regarding the implementation and appliance of AIPSAS will create a platform for the Ghanaian public sector to meet an international standard. Accounting practitioners in the public sector should be able to access training materials to enable them to update themselves on financial reporting standards. 


\section{Ml Macrothink}

International Journal of Accounting and Financial Reporting

ISSN 2162-3082

2018, Vol. 8, No. 2

This quantitative study additionally suggests that the incorporation of IPSAS, more particularly AIPSAS, in the academic educational module of both polytechnics and universities will limit the challenges of the implementation of such a standard. The inclusion of public sector accounting modules into the educational module is an indication of preparing future accountants to be responsible for the accounting systems in the public sector of Ghana.

This quantitative research again uncovered that there is absence of a methodological correlation between the available laws of Ghana and IPSAS. Thus, this empirical research once more suggests that bodies in charge of regulating the accounting systems in Ghana should be part at the international level where the internal accounting standard is set. This will bring about synchronisation of local accounting laws and that of IPSAS.

This research additionally demonstrated that the enforcement and implementation costs of IPSAS are too high. Hence, this quantitative research proposes that a government subsidy is needed for the successful implementation and enforcement of a new standard. The implementation of AIPSAS in the public sector of Ghana will support the assurance of the accounting regulatory bodies in the implementation of IPSAS. The AIPSAS implementation in the MMDAs in the public sector of Ghana will guarantee the financial reports' harmonisation which will thus make efficient use of state resources. Once more, government subsidies will help the local accounting regulatory bodies to create awareness of IPSAS amongst the accounting practitioners and other interest groups.

\section{Acknowledgements}

We thank Dr. V. Kurma and Prof. P. Mohanamani (Texila American University) for their support of the article.

\section{References}

Alp, A., \& Ustuntag, S. (2009). Financial reporting transformation the expedience of Turkey. Critical Perspective on Accounting, 20, 680-699. https://doi.org/10.1016/j.cpa.2007.12.005

Chan, J. L. (2006). IPSAS and government accounting reform in developing countries. In Lande, E., \& Scheid, J.C., (Eds.), Accounting reform in the public sector: mimicry, fad or necessity? Paris: CIGAR (Comparative International Governmental Accounting Research).

Cooper, D. R., \& Schindler, P. S. (2003). Business Research Methods (8th ed.). New York: McGraw Hill.

Eldabi, T., Irani, Z., Paul, R.J., \& Love, P.E.D. (2002). Quantitative and qualitative decision-making methods in simulation modeling. Management Decision, 40(1), 64-73.

Ernest and Young. (2010). IPSAS Pros and Cons for New Zealand. Ernest \&Young.

IFAC. (2012, March). Public Sector Financial Management Transparency and Accountability: The Use of International Public Sector Accounting Standards. 529 Fifth Avenue, 6th Floor, New York. Retrieved from www.ifac.org 


\section{Macrothink}

International Journal of Accounting and Financial Reporting

ISSN 2162-3082

2018, Vol. 8, No. 2

International Federation of Accountants (IFAC). (2015). IPSASB Publishes Five IPSAS Based on the IASB's 'Package of Five', 545 Fifth Avenue, 14th Floor, New York, Retrieved February 24, 2015, from www.ifac.org

IPSASB. (2013). Handbook of International Public Sector Accounting Pronouncements. 545 Fifth Avenue, 14th Floor, New York. Retrieved October 22, 2014, from www.ifac.org

Irvine, H.J., \& Lucas, N. (2006). The rationale and impact of the adoption of international financial reporting standards on developing nations: the case of the United Arab Emirates. In proceedings 18th Asian Pacific Conference on international Accounting Issues, pp.1-22, Maui, Hawaii. Retrieved from Available http://eprints.qut.edu.au/13041

Martins, V W. (2011). Practical challenges in IFRS implementation. What bank regulators need to know. IFRS International conference-Nigeria KPMG.

Mugenda, A. G. (2008). Social Science Research: Theory and Principles. Nairobi: Applied Research \& Training Services.

Neter, J., Kutner, M. H., Nachtsheim, C. J., \& Wasserman, W. (1996). Applied linear statistical models. 4. Chicago: Irwin.

Nkwagu, L., Chinedu1, U., Leonard, C. N., \& Friday, E. (2016). Implications of International Public Sector Accounting Standards on Financial Accountability in the Nigerian Public Sector: A Study of South Eastern States. Retrieved 6 December 2016, from http://iosrjournals.org/iosr-jbm/papers/Vol18-issue7/Version-4/M180704105118.pdf

Omane-Antwi, K. B. (2016). Ghana Adopts International Public Sector Accounting Standards (IPSAS); stakeholder's forum and launch of IPSAS in Accra on 11 February 2016. Retrieved 6

December 2016, from http://www.ghana.gov.gh/index.php/media-center/news/1114-ghana-adopts-international-pub lic-sector-accounting-standards-ipsass-for-the-public-sector

Resnik, D.B. (2011). What is ethics in research and why is it important?. Retrieved14 December 2016, from from:http://www.niehs.nih.gov/research/resources/bioethics/whatis

Sekaran, U. (2003). Research Methods for Business- A Skill Building Approach. New York: John Wiley \& Sons, Inc.

\section{Copyright Disclaimer}

Copyright for this article is retained by the author(s), with first publication rights granted to the journal.

This is an open-access article distributed under the terms and conditions of the Creative Commons Attribution license (http://creativecommons.org/licenses/by/4.0/) 